thrown by the lens in front of it. It is possible indeed to show in actual fact that the image in the eyeball is inverted; the experiment is very simple, but we believe that this is the first time that it has been described in print. Take a candle, and hold it in your right hand as you stand opposite a looking-glass. Turn your head slightly to the left while you look at the image of yourself in the glass. Open your eyes very wide and look carefully at the image of your left eye. Move the candle about gently, up, down, forward, \&c., so that the light falls more or less obliquely on to the eyeball. You will presently notice a little patch of light in the extreme outer corner of the eye; it is the image of the candle on the inside of the eyeball, which you see through the semi-transparent horny substance of the eye. If you move the candle up, the little image moves down, and if you succeed well, you will discern that it is an inverted image, the tip of the flame being downwards. You thus prove to your own satisfaction that the image of the candle in your eyeball is really upside down.

Fig. 23 shows a magnifying-glass of very simple con- struction, which a few years ago found a great sale in the streets of London, at the price of one penny. A bulb blown at the end of a short glass tube is filled with water. When held in front of the eye, this form a capital lens for examining objects of microscopic dimensions, which may be secured in place by a bit of wire twisted round the stem.

The principle by which the intensity of two lights is compared in the photometer is very easily shown. The arrangement depicted in Fig. 24 shows how to measure the relative brightness of an Argand oil-lamp and of an ordinary candle. Both these lights are set upon the table, and are so arranged that each casts on to a screen of white paper a shadow of a tall narrow object. The most handy object for this purpose is another candle unlighted. The Argand lamp, being the brighter light, will cast the deeper shadow of the two, unless it is placed further away. The measure of the brightness is obtained by moving the brighter light just so far off that the intensity of the two shadows is equal, for then we know that the relative intensities of the

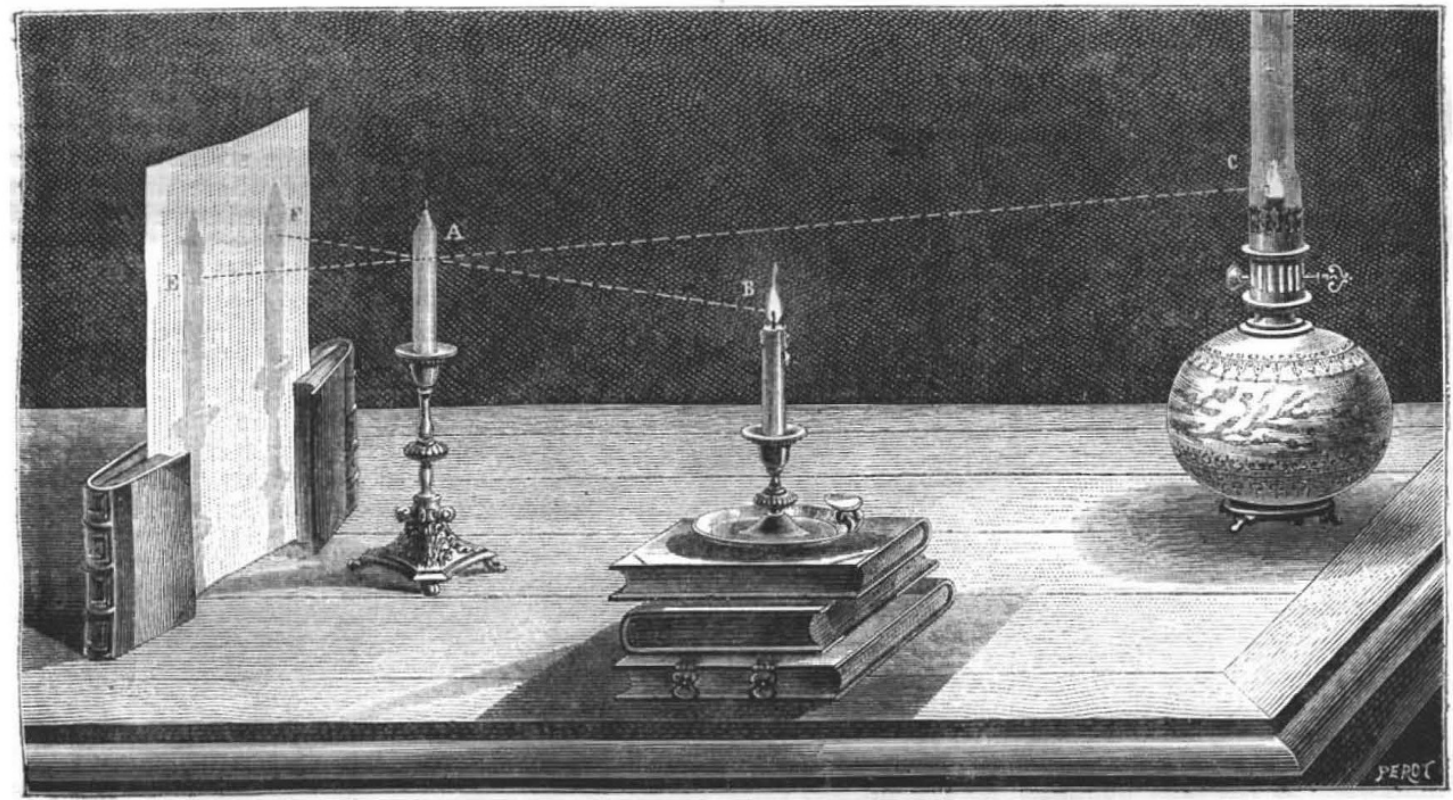

FiG. 24.

two lights are proportional to the squares of their distances from the photometer. All that remains, therefore, is to measure the distances and calculate out the intensities. If, for example, the distance of the lamp is double that of the candle when the two shadows are equally dark, we know that the brightness of the lamp is four times as great as that of the candle.

Many other facts in optics can be shown with no greater trouble than that entailed by such simple experiments as we have described. The pendant lustre of a chandelier will provide an excellent prism of glass for showing the dispersion of light into its component tints. A couple of spectacle glasses appropriately chosen will, when pressed together, afford capital "Newton's rings" at the point where they touch. Diffraction bands of gorgeous hue may be observed by looking at a distant gas-light, or at the point of light reflected by a silvered bead in sunshine, through a piece of fine gauze, or through a sparrow's feather held close in front of the cye. And yet more remarkable effects of diffraction are obtained if the point of light be looked at through substances of still finer structure, such as the preparations of woody structure, and of the eyes of insects which are sold as microscopic objects. But the explanation of these beautifull phenomena would lead us far beyond our subject.

( To be continued.)

\section{THE JAMAICA HURRICANE AND THE BOTANICAL GARDENS}

THE following letter from Mr. Morris has been forwarded to us from Kew for publication :-

\section{Botanical Department, Gordon Town Jamaica, September 7, 1880}

At the Cinchona Plantation, besides damage to our buildings and sheds of about $650 \%$., our nurseries and seed beds have suffered so much as to reduce our stock of available seedlings from something like 500,000 down to 80,000 . These were intended for planting out in the latter part of this year and the beginning of the next year. We shall in consequence be unable to distribute seedlings as we intended, and so suffer considerably in expected 
revenue. At the plantations vegetation is so literally swept away that only here and there can we see a standing tree. There is not a leaf left on either the indigenous or cinchona-trees. After a careful inspection we have estimated that 20,000 cinchona-trees of all ages have been uprooted or so severely damaged that they must be immediately barked. Though we had given up barking definitely till the return of dry weather next year, we are now obliged to take it up with great energy and send the bark down to be dried in the plains. We hope to get a return of about $\mathrm{x}, 5 \mathrm{00l}$. to $\mathrm{I}, 800 \mathrm{l}$. for "broken and twiggy" bark, but this will be but a poor result considering the sacrifice made to secure the bark at all hazards before it has dried and hardened on the trees.

Out of the small garden at Castleton, covering only about five to six acres, I found fifty-five trees destroyed, and ninety-eight severely injured. Out of the trees severely injured, i.e. probably blown quite down and put up again with trimmed limbs and supports, I found the Para-rubber mangosteen, Tonquin-bean, cam-wood, olive, cinnamon, nutmeg, East Indian mango, chocolate, Liberian coffee, \&c. Even if they live we shall get no fruit from them during the next season, and we shall be unable to supply plants in great demand for some time.

I am glad to say that the superintendent did not suffer personally, though the roof of the residence was partially blown away, and the office canted almost on its side.

The Parade Garden, Kingston, felt the hurricane greatly, but as we had nothing there except ornamental trees and shrubs we hope to recover our losses soon.

The cocoanut plantation at the Palisadoes had sixty-one bearing trees blown down, and forty-one rather young ones just coming into bearing. This plantation is on a narrow spit of sand running six miles out and inclosing Kingston Harbour. The force of the wind being from the south and against the plantation, the waves broke over it at several places, and the harbour being consequently filled, much damage was done to the wharves and shipping.

You will, I am sure, be sorry to hear that the Old Bath Garden has also shared in the general injury. The fine old cinnamon-tree, the camphor-tree, and the pinus are down. Till the place is cleared the keeper is unable to give me fuller particulars.

The King's House Gardens and grounds have fortunately escaped much injury.

D. MORRIS

\section{NOTES}

Messrs. Charles Griffin and Co. announce that they have at last in the press the memorial volume to the late Prof. Macquorn Rankine. It is entitled "A Selection from the Miscellaneous Scientific Papers of W. J. Macquorn Rankine, C.E., LL.D., F.R.S., late Regius Professor of Civil Engineering and Mechanics in the University of Glasgow, from the Transactions and Proceedings of the Royal and other Scientific and Philosophical Societies, and the Scientific and Engineering Journals, with an Introductory Memoir of the Author, by P. G. Tait, M.A., Professor of Natural Philosophy in the University of Edinburgh; edited by W. J. Millar, C.E., Secretary to the Institution of Engineers and Shipbuilders in Scotland." The volume will contain many papers of great weight and value, at present to be found only in the Records of the various scientific and philosophical societies, and in the scientific and engineering journals, to which they were originally contributed, and therefore inaccessible to the majority of scientific workers. No doubt the bringing-tngether in one volume of these successive important contributions to science will be acceptable to all who knew of Rankine's high position in science. A fine portrait on steel will be prefixed to the volume.

WE have a few further details on the meeting of the German Association at Danzig. Salzburg was unanimously chosen as the town in which the next year's congress of the Association should be held. Dr. Wernicke of Berlin gave an address "On the Scientific Standpoint in Psychiatry," and in the section for physics and meteorology Dr. L. Weber read a paper upon "Lightning Strokes in Schleswig-Holstein." In the section for the supexintendence of instruction in mathematics and natural science Dr. Feyerabendt spoke with reference to mathematical school-books, which, as he showed, would bear much simplification and condensation. A point which he urged among others was that the matter taught should be divided, not upon scient fic principles, but with regard to its easy and ready comprehension by the scholar.

THE death is announced, on August 22, of the Hon. John Imray, M.D., of Dominica, West Indies. Dr. Imray had done much for the botany of his island, but is best known for his successful efforts to introduce Liberian coffee and the cultivation of limes into the West Indies. Another death is that of M. Edmond Barbier, the translator into French of some of the works of $\mathrm{Mr}$. Herbert Spencer and Sir John Lubbock, at the age of forty-six years.

A LAUDABLE innovation has been made in the library of the French Academy, which is not open to the public. Any one wishing to consult any of the rare and precious books in the library has only to make an application to the librarian to receive the required authority.

DR. WATT, of the Bengal Educational Department, who is now engaged in the examination at Kew of his extensive collections of Indian plants, has been deputed by the Government of India to visit Manipur, on his return from furlough, for the purpose of reporting on the forest and vegetable resources of that territory.

Science, the new American record of scientific progress, states that the Rev. W. H. Dallinger has consented to become Governor and Professor of Natural Sciences of Wesley College, Sheffield, U.S.A.

Mr. JAMES BLyth of Edinburgh has been elected to succeed Prof. Forbes in the Chair of Natural Philosophy at Anderson's College, Glasgow.

Dr. J. Vosmar of the Hague intends publishing a detailed bibliography of the sponges, and it is to be hoped that all authors of works or papers on this interesting group will send copies of their writings to him at 73, de Ruyter Straat, Haag, Holland.

THE bureau of French meteorology has been revived for 1880-81, M. Hervé Mangon being continued president.

THE recent change of Ministry in France has brought forward for the second time since 1870 the Minister of Public Instruc. tion to the direction of the Cabinet. M. Barthelemy St. Hilaire, the new head of the French Foreign Office, is not only a member of the French Senate, but also of the Academy of Moral and Political Sciences. He has published a large number of works on philosophy, among which the most considerable is a translation of the whole works of Aristotle, with a commentary. In order to be better able to understand physics and mechanics, he studied mathematics at the age of forty-five under the direction of his friend Corioles, then scientific director of the Polytechnic School. He was an intimate friend of Leverrier. He was born in Paris in 1809 , and has just completed his seventy-first year.

THE Birmingham Natural History Society, which has hitherto met in the Midland Institute, has been provided with ample accommodation in the Mason Science College. The Society, which numbers 400 members, is making an effort to fit up the rooms in an appropriate and comfortable manner. 